\title{
The Labor Market in Romania and Interregional Disparities
}

\author{
Nela Steliac \\ "Babes-Bolyai" University of Cluj-Napoca, Romania
}

\begin{abstract}
The decrease of regional disparities represents one of the fundamental objectives of the regional development policy promoted by the EU; furthermore, the waves of enlargement of the EU deepened these differences even more. As a member state of the EU, Romania is actively involved in reducing the economic gaps by applying some regional development strategies and policies. The aim of this paper is to present the results of the labor market analysis from the perspective of the regional gaps, carried out based on some of its specific indicators. The sinuous evolution of the standard deviation for the analyzed indicators (except for the net average salary the standard deviation of which was permanently growing) revealed increase or decrease of the regional disparities for the entire period. However, in comparison to 1998, the regional gaps increased in 2013. The regional poles on the labor market have been as following: Bucharest-Ilfov region for the best values of the studied indicators, and Northeast region and Southwest Oltenia region for the lowest values.
\end{abstract}

Keywords: Labor market, Interregional disparities, Convergence, Divergence

\section{Introduction}

By the Treaty of Rome (Title XVII, article 158) the legal basis of the regional development policy (RDP) was established at the European Economic Community (EEC) level, which aimed at 'reducing disparities between the development levels of different regions and the shortfall of disadvantaged regions or islands, including rural areas' (www.europarl.europa.eu, 2015). Until the 1970s the problem of international disparities was among the priorities of the national governments of EEC. Starting from the middle of the 1970s the foundations of RDP were laid down at community level (Luțaș \& Câlea, 2005, p.99). The successive rounds of enlargement of the EU deepened the regional disparities in the Community even more. Currently, the objectives of RDP aim at three different territorial levels: EU level; member state level; territorial unit level which include more states. As a member state of the EU, Romania is also engaged in reducing disparities and strengthening the economic and social cohesion at regional level.

If before 1989 interregional disparities had a relatively low level compared to Western European economies (Zaman et al., 2013, p.21) or to other former communist countries from Eastern Europe (Diaconu, 2014, p.77), after the abandonment of the communist regime the disparities deepened. The causes are manifold. Among them we can mention the following: different natural and human resources (Oțil \& Părean, 2010, p.267; Goschin et al., 2008, p.82), economic structure of regions (Antonescu, 2012, p.9; Cârnu, 2010, p.77), Romania's reduced capacity to absorb structural funds for regional development (Zaman et al., 2013, p.21), different regional attraction of capital in general and direct foreign investments in particular (Zaman et al., 2011, p.14; Nistor, 2012, p.742; Zaman et al., 2013, p.21), with negative effects on economic disparities, advantageous geographic location compared to other EU member states for some regions (Diaconu, 2014, p.78), differences in infrastructure (Russu, 2014, p.27), etc.

This paper aims at analyzing the labor market in Romania from the perspective of interregional disparities. In this sense, we processed some INSSSE and EUROSTAT statistical data, which relate to this type of market. In their analysis we mainly used the method of dispersion. In order to estimate the level of territorial concentration, we calculated the Gini-Struck concentration coefficient, and in order to identify the types of positive/negative influences of the national, sectorial and regional factors upon the employed population and the number of employees, we applied the Shift-Share method. For this latter method TEMPO-ONLINE regional statistical data on employed population and 
number of employees were used for the three large economic sectors: agriculture, industry and constructions, and total services, of the year 2013 in comparison to 1998.

The indicators monitored in the paper were the following: GDP/inhabitant, employed population, number of active enterprises, number of employees, activity ratio, unemployment ratio, job vacancy ratio, average monthly net salary. The analyzed period included the years between 1998 and 2013. This period was chosen for two reasons. Firstly, as 1998 is the year when Law 151 on regional development in Romania (replaced since 2004 by Law 315) was adopted, by which the establishment of development regions was decided. Secondly, a longer period of time can offer a better and more complete image on the evolution of regional gaps.

\section{Short Review of Domestic Literature}

The problem of economic and social gaps was tackled by a series of specialists. Foreign and domestic literature is extremely numerous and varied in this kind of papers. The papers published by Romanian authors dealt with this topic separately or simultaneously at EU level or/and national level. Similarly, some of the authors addressed this subject matter as a whole at the level of all regions or at the level of 1-2 regions of the country. The period to which reference is made in the majority of domestic papers is the period following the years 2007/2008 and less the previous period.

In the following report we will mention only a few of those which caught our attention in a special way, without any claim to cover all the papers published lately in the field.

For instance, Goschin et al. (2008) built a composite index for the analysis of interregional disparities taking into account the following: GDP/inhabitants, net monthly average income and unemployment rate. In his paper, Pintilescu (2011) explains the regional disparities in Romania for the period 1990-2008 and identifies the economic profile of the regions. The same scientific approach is adopted by Jaba (2009), that is, the identification of regional profile takes into consideration statistical data from 2005. In his paper, Dimian (2012) supports that between the imbalances of the labor market and regional disparities there is a biunique relation. He analyses the way in which the imbalances of the labor market influence the future development of the regions, while the period studied was 2000-2008.

According to Russu (2014), regional disparities are given as well as by the existing lacunae in different fields: energy, transport and communication infrastructure, education, science and technology, tourist attraction etc. Barabaş (2014) manages to determine the defining characteristics of the Romanian counties, classifies them depending on their economic performances and uses indicators such as GDP, population employment and labor force rate, average salary, unemployment expenses.

Simionescu (2014) carries out the analysis of beta convergence for the period 2001-2012 in order to highlight regional disparities within EU28. In European as well as national context the problem of regional disparities is dealt with by Antonescu (2012) and Chirilă \& Chirilă (2014). Antonescu carries out the analysis of regional disparities with the method of dispersion and Lorenz-Gini curve for the period 1999-2008 using a series of economic, demographic and social indicators. Chirilă \& Chirilă study (for the end of 2006 and 2009) the evolution of regional disparities based on multivariable analysis of data using as variables: incomes of private households, population employment rate, human resources, GDP and unemployment rate.

Moisescu (2015) studied the degree of regional convergence/divergence of Romania for the period 2000-2010 is by means of sigma convergence and beta convergence. Stanef (2014) analysed a more current period (2007-2010) of interregional disparities by for urban and rural environment. Comparative analyses of interregional disparities between two regions were carried out by authors such as Diaconu (2014) and Rotaru (2014). Diaconu focuses his attention on NE and W regions for the period 2007-2012. Rotaru carries out an empirical study on factors influencing employment rate of the same regions. He underlines that there are significant discrepancies between the two regions in terms of GDP/inhabitant, income and employment rate. He states that the productivity of work is directly related to employment rate while household income is positively correlated with the employment level of regions. 


\section{A General View on Interregional Disparities in Terms of GDP/Inhabitant}

The most relevant indicator in estimating the interregional disparities is GDP per capita. If we relate to the EU27 average, then we must say that only Bucharest-Ilfov (BI) region managed to rank above the average starting from 2008, reaching values up to $+22 \%$ in 2011. All other regions registered values far below the European average, 6 out of 8 being ranked, from this point of view, among the last 20 regions within EU in 2008 (Albu et al., 2011, p.27). The BI region is followed at a significant distance, however, by West region, with values up to $54 \%$ of the European average. The lowest GDP/inhabitants. Values in PPS compared to the average EU27 were registered in 2007 in the NE region, $26 \%$ of the average.

There are major discrepancies between the regions in Romania. In order to follow the evolution of interregional differences we calculated the variability indicators, the indicators presented in Fig. 1:

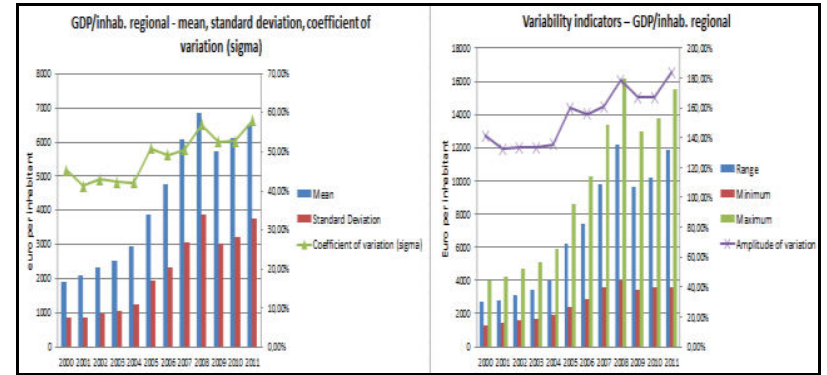

Fig. 1 Variability indicators - GDP/inhab. regional (current market price)

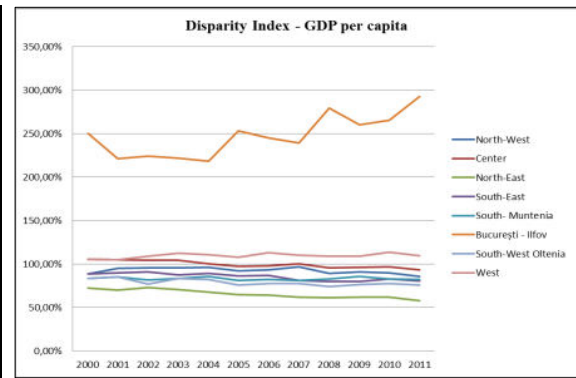

Fig. 2 Disparity index GDP/inhab. compared to national average $(=100)$

Source: own calculations carried out based on EUROSTAT data

At the national level, two stages of GDP/inhabitants growth can be distinguished, that is, between 1998-2008 and 20092011, respectively. In these periods a constant upward trend of GDP/inhabitants value (both by average and minimum and maximum value) is registered, which means that on the whole, the level of economic development increased. The year 2009 (first year of construction in economy after the breakout of the current economic and financial crisis) interrupts the favorable evolution of GDP/inhabitants. In the next 2 years, however, this indicator followed an upward trend.

Regarding the interregional disparities, in general, we can notice an increase (see fig. 1). An increase of GDP dispersion takes place at regional level, that is, an accentuation of discrepancies compared to the national average, from $45.36 \%$ in 2000 to $58.04 \%$ in 2011 . In the last part of the period a decrease can be noticed, however, in the value of dispersion to $52.68 \%$ in 2009 . As such, in the analyzed period, a downward trend in the regional convergence was registered, or, in other words, a divergent upward trend of the regional economic activity. The coefficient of variation, called also sigma coefficient, characterizes the level of convergence by measuring dispersion of GDP per inhabitant in a year.

At the same time, from the calculations made, except for the year 2001, 2002, 2006 and 2009, results that the rate of growth of maximum level of regional GDP/inhabitants was higher than of the minimum level. This fact explains as well the relatively increasing level of indicator amplitude. The minimum and maximum levels are registered constantly by the two regional poles: NE region (for minimum) and BI region (for maximum). In the period 2000-2011, the maximum GDP/inhabitants level significantly increased from 4,000 Euros/inhabitants to 15,500 Euros/inhabitants, a growth of $287.5 \%$, while the minimum value increased from 1,300 Euros/inhabitants to 3,600/inhabitants - a growth of $176.9 \%$. The difference between the highest and the lowest value registered by GDP/inhabitants in 2011 was approximately of 4.3 to 1 .

Further on, the evolution of disparity index (Fig. 2) shows extremely great differences at the level of the two poles. Thus, if in the case of the Northeast region in general a decrease of this index can be noticed, in the case of BI region a fluctuating evolution is registered. Nevertheless, the disparity index of BI region exceeds the value of $200 \%$.

\section{9}


Noteworthy is also the decrease of the disparity index compared to the first year of the period studied (except for the W and BI regions).

\section{The Labor Market in Romania - Convergence or Divergence}

The 1990s bring significant changes in the volume and structure of the main indicators of the labor market in Romania (Stanef, 2014, p. 62). In order to follow these changes, which can highlight regional convergence/divergence, in the following we analyses the following indicators:

\subsection{Population employment}

The population employment in Romania has steadily declined after the 1990s, mainly as a result of the massive economic restructuring. Currently, the population employment rate sets around $60 \%$, under the level $70 \%$ established by the National Reform Program 2015 necessary to achieve the objective EU2020 in terms of employment and fight against poverty. The population employment decreased in the period 1998-2013 by 282 thousand persons, from a total of 8,812.6 thousand person to 8,530.6 thousand persons.

The interregional discrepancies on population employment can be noticed in the figure below. According to this figure, except for BI and West regions, all the other regions registered decrease in population employment.

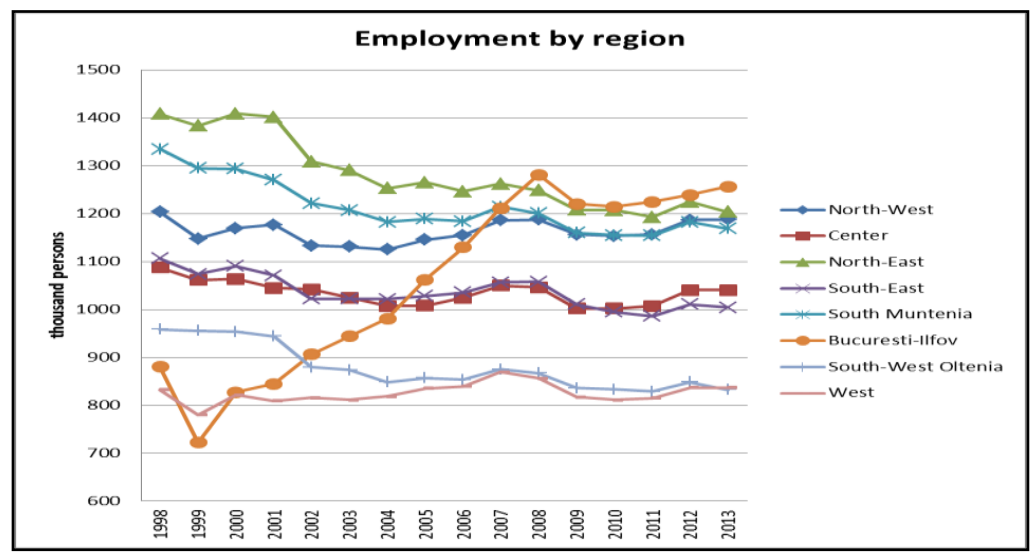

Figure 3: Population employment by regions (1998-2013)

Source: Diagram drawn up by the author based on TEMPO-ONLINE data

These disparities are highlighted as well by the influences of the national, sectorial and regional factors, on population employment decrease. The results of Shift-Share analysis are given below.

Table 1: Shift-Share analysis by regions - employment (thousand persons)

\begin{tabular}{|c|c|c|c|c|}
\hline \multirow[t]{2}{*}{ Region } & \multirow{2}{*}{$\begin{array}{c}\text { Absolute change of } \\
\text { population } \\
\text { employment } \\
2013 / 1998(\Delta E R)\end{array}$} & \multicolumn{3}{|c|}{ Breakdown by factor of the absolute change of population employment: } \\
\hline & & $\begin{array}{c}\text { National component } \\
(\mathrm{Nr})\end{array}$ & $\begin{array}{l}\text { Sectorial component } \\
\text { (Sr) }\end{array}$ & $\begin{array}{c}\text { Regional component } \\
\text { (Rr) }\end{array}$ \\
\hline North-West & $-15,600$ & $-38,515$ & $-24,476$ & 47,391 \\
\hline Center & $-47,200$ & $-34,816$ & 8,462 & $-20,846$ \\
\hline North-East & $-204,400$ & $-45,059$ & $-51,015$ & $-108,326$ \\
\hline South-East & $-102,700$ & $-35,411$ & $-5,829$ & $-61,460$ \\
\hline South & $-166,400$ & $-42,726$ & $-54,321$ & $-69,353$ \\
\hline Bucharest-Ilfov & 376,900 & $-28,160$ & 150,071 & 254,988 \\
\hline South-West & $-126,500$ & $-30,672$ & $-38,603$ & $-57,225$ \\
\hline West & 3,900 & $-26,643$ & 15,711 & 14,831 \\
\hline
\end{tabular}

Source: Own calculations based on TEMPO-ONLINE data 
The data presented in the table above indicate a decrease in population employment in 2013 compared to 1998 in the majority of the regions. Only Bucharest-Ilfov and West regions make an exception. The highest decrease was registered in Northeast region (the poorest region in the country), over 204 thousand people, and the lowest decrease in the Northwest region, over 15 thousand individuals. BI region has the highest growth rate, with over 376 thousand people. The national component affected negatively the absolute change of population employment in the period 2013/1998 for all of 8 regions. The sectorial component determined decrease in employment in Northwest, Northeast, Southeast, South, Southwest regions and growth for the other three regions (Centre, Bucharest-Ilfov, West). The last three regions are specialized in branches of economy with rapid growth, and this is because the value of $\mathrm{Sr}$ is positive. The highest positive sectorial influence can be noticed in the case of BI region. The regional component determined decrease in population employment for $\mathrm{C}, \mathrm{NE}, \mathrm{SE}, \mathrm{S}, \mathrm{SW}$ regions. NW, BI and $\mathrm{W}$ regions have a positive regional component combined either with a negative sectorial component (NW region), or a positive sectorial component (BI and $\mathrm{W}$ regions).

Interregional disparities exist as well in terms of population employment structure in the three big sectors: agriculture, industry and constructions, and services. From this point of view important changes in this structure (see Table 2) can be noticed. The first remark would be related to the reconfiguration of the economic profile of regions from the perspective of population employment. In this sense, a reorientation of the population employment from agricultural sector, predominantly in 1998 in the majority of the regions (except for Central and BI regions) can be noticed towards the services sector. From this point of view the percentage decrease of population employment in the agricultural sector is significant for some regions. Thus, NW region, predominantly agricultural, becomes a region with population predominantly employed in the services sector. The same happens in the case of SE and West regions. The Central region is transformed from an industrial area into an area dominated by services. However, NE and SW regions still remain regions where more than 1/3 of population employment belongs to agriculture. As such, NE, SW regions and as well BI region continue to keep the economic profile. In BI region the majority of the population employment can be found in the services sector, a sector which attracts in 2013 a greater part of the population (over $71 \%$ in 2013 compared to approximately $55 \%$ in 1998).

The second conclusion is related, on one hand, to the downward trend of population employment in the agricultural and constructions sector, and on the other hand, to the upward trend of population employment in the services sector.

At BI level both the greatest decrease of population employment (in industry and constructions: $-13.52 \%$ ) and the greatest increase (services sector: $16.25 \%$ ) were registered.

Table 2: Population employment by sectors and development regions (\%)

\begin{tabular}{|c|r|r|r|r|r|r|r|r|r|}
\hline \multirow{2}{*}{ Region } & \multicolumn{3}{|c|}{ Year 1998 } & \multicolumn{3}{|c|}{ Year 2013 } & \multicolumn{3}{c|}{$\pm \Delta \mathbf{2 0 1 3 / 1 9 9 8}$} \\
\cline { 2 - 10 } & $\mathbf{1}$ & $\mathbf{2}$ & \multicolumn{1}{|c|}{$\mathbf{3}$} & $\mathbf{1}$ & $\mathbf{2}$ & $\mathbf{3}$ & \multicolumn{1}{c|}{$\mathbf{1}$} & $\mathbf{2}$ & \multicolumn{1}{c|}{$\mathbf{3}$} \\
\hline North-West & 41.72 & 29.99 & 28.29 & 30.13 & 29.92 & 39.94 & -11.59 & -0.07 & 11.65 \\
\hline Center & 31.50 & 38.15 & 30.35 & 22.89 & 33.88 & 43.24 & -8.61 & -4.27 & 12.89 \\
\hline North-East & 47.44 & 25.46 & 27.10 & 40.06 & 22.80 & 37.14 & -7.38 & -2.66 & 10.04 \\
\hline South-East & 41.44 & 27.17 & 31.38 & 32.26 & 27.16 & 40.57 & -9.18 & -0.01 & 9.19 \\
\hline South & 44.37 & 30.65 & 24.98 & 35.86 & 28.23 & 35.92 & -8.51 & -2.42 & 10.94 \\
\hline Bucharest-Ilfov & 5.63 & 39.34 & 55.03 & 2.90 & 25.82 & 71.28 & -2.73 & -13.52 & 16.25 \\
\hline South-West & 47.76 & 25.87 & 26.36 & 38.86 & 25.61 & 35.53 & -8.9 & -0.26 & 9.17 \\
\hline West & 34.00 & 32.33 & 33.67 & 23.78 & 34.25 & 41.97 & -10.22 & 1.92 & 8.3 \\
\hline
\end{tabular}

Legend: 1 - Agriculture; 2 - Industry \& constructions; 3 - All services

Source: Own calculations based on TEMPO-Online data

\subsection{Number of active enterprises}

According to the chart below, until 2008 inclusively, an accentuation of interregional disparities took place in terms of number of active enterprises. The period 2009-2011 is characterized by the growth of regional convergence, but the interregional disparities register again an upward trend in the following two years. 


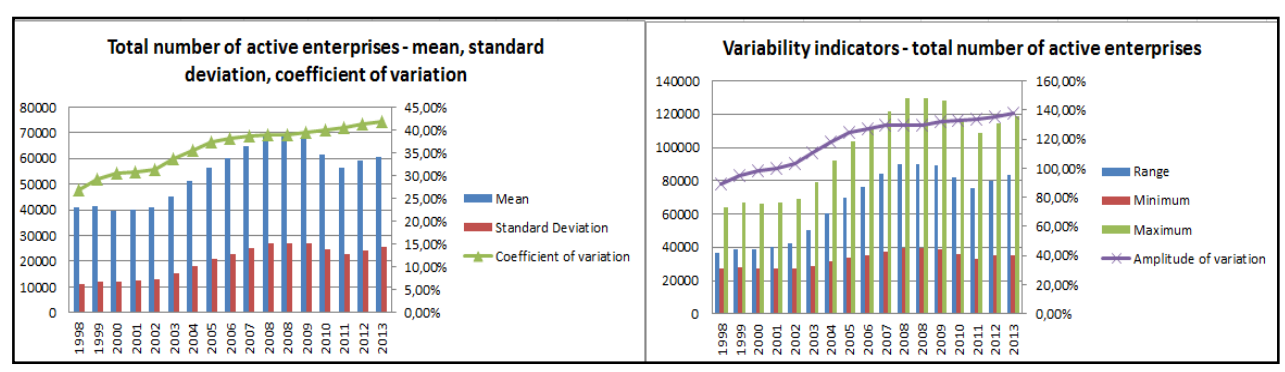

Figure 4: Variability indicators - total number of active enterprises

Source: Own calculations based on TEMPO-Online data

In absolute magnitudes, the total number of active enterprises decreased in 2013 compared to 2008 with 69,885 units, which means that in this period approximately $12.59 \%$ of the economic units existing at the end of 2008 stopped their activities. This fact can also be noticed in the table below. However, what catches the attention is the evolution of the number of active enterprises in the agricultural field. In contrast to the rest of the economic sectors, in the case of the agricultural sector an upward trend can be noticed concerning the number of active companies in the studied period. At national level this growth was of $23.2 \%$. By regions, the growth was, however, different. For instance, in SW Oltenia region the highest value of growth was achieved, over $34 \%$, followed at a distance of $4 \%$ by SE region. Both are traditionally agricultural regions.

At national level, the greatest decrease in the number of enterprises can be noticed in constructions, approximately $23 \%$, while the lowest decrease can be noticed at the level of service provision sector, of only $3.45 \%$.

Another interesting aspect to be underlined is the fact that at the level of regions four economic sectors (industry, constructions, trade and agriculture) keep the trend registered at national level (downward or upward). The services sector makes an exception. From this point of view we notice regions which "declare" increase in the number of active companies in the services sector, but as well regions with decreases. For instance, in the Central region a decrease with $8.18 \%$ of these companies was registered, and in South-Muntenia region an increase with $4.34 \%$.

Similarly, it must be mentioned as well that, as expected, most of the enterprises operate in BI region, over 118,000 in 2013. BI region is followed by NW with over 68,000 enterprises. The fewest companies carry out their activity in the Southwest region, a bit over 35,000 trading units (by 3.36 times fewer compared to BI region). In table 4, we notice that in every region there was a trend of change in ratio of the five main sectors. If we think of increase, then we must mention the agricultural and services sector. The percentage criteria are, however, different from one region to the other. The most significant increase of the number of agricultural enterprises in the total number of enterprises can be noticed in the case of Southeast region (1.85\% in 2013, compared to 2008). At the counterpale we find Bucharest-Ilfov region (an increase with $0.17 \%$ in 2013 compared to 2008).

Concerning the services, the highest growth was registered at the level of Southern-Muntenia region (5.04\% in 2013 compared to 2008). At the same time, however, for the same region, the lowest percentage of active enterprises in the field of services can be noticed, in total number of active enterprises, that is, approximately $34 \%$. For the rest of the regions, this increase was around 4\%. Noteworthy is, however, also the fact that services from BI region $(50.60 \%$ in 2013) have the highest ratio of the active enterprises at regional level.

The industrial sector basically keeps or slightly decreases in terms of the ratio of the number of enterprises in total by regions. Compared, however, to the rest of the regions, the Central region registers the highest value in 2013 (over $13 \%$ ), while Bucharest-Ilfov region achieves the lowest value (approximately 7\%). 


\section{Nela Steliac}

The Labor Market in Romania and Interregional Disparities

Table 3: Number of active enterprises by main sectors and regions - 2008-2013

\begin{tabular}{|c|c|c|c|c|c|c|c|c|}
\hline Sectors & Region & 2008 & 2009 & 2010 & 2011 & 2012 & 2013 & $\pm \Delta I$ 2013/2008 \\
\hline \multirow[t]{9}{*}{ Total } & Total & 554967 & 541696 & 491805 & 452010 & 472187 & 485082 & $-12.59 \%$ \\
\hline & NW & 78750 & 75885 & 67871 & 62381 & 65752 & 68205 & $-13.39 \%$ \\
\hline & $\mathrm{C}$ & 68001 & 66018 & 59253 & 54304 & 56069 & 57245 & $-15.82 \%$ \\
\hline & NE & 60898 & 59051 & 53165 & 48591 & 50298 & 51395 & $-15.60 \%$ \\
\hline & SE & 65495 & 64033 & 58225 & 53221 & 55156 & 56292 & $-14.05 \%$ \\
\hline & $\mathbf{S}$ & 59482 & 58214 & 53686 & 49587 & 51563 & 52890 & $-11.08 \%$ \\
\hline & BI & 129940 & 128347 & 117679 & 108764 & 114816 & 118819 & $-8.56 \%$ \\
\hline & SW & 39780 & 38967 & 35956 & 33258 & 34849 & 35360 & $-11.11 \%$ \\
\hline & $\mathbf{W}$ & 52621 & 51181 & 45970 & 41904 & 43684 & 44876 & $-14.72 \%$ \\
\hline \multirow[t]{9}{*}{ Agriculture } & Total & 13602 & 15112 & 15240 & 15152 & 16080 & 16758 & $23.20 \%$ \\
\hline & NW & 1718 & 1927 & 1898 & 1862 & 1994 & 2142 & $24.68 \%$ \\
\hline & $\mathrm{C}$ & 1730 & 1949 & 1922 & 1890 & 2018 & 2085 & $20.52 \%$ \\
\hline & NE & 1839 & 2056 & 2022 & 2004 & 2099 & 2149 & $16.86 \%$ \\
\hline & SE & 2348 & 2672 & 2745 & 2778 & 2922 & 3059 & $30.28 \%$ \\
\hline & $\mathbf{S}$ & 2369 & 2600 & 2732 & 2744 & 2867 & 2972 & $25.45 \%$ \\
\hline & BI & 800 & 821 & 848 & 838 & 910 & 937 & $17.13 \%$ \\
\hline & SW & 1033 & 1185 & 1205 & 1190 & 1313 & 1387 & $34.27 \%$ \\
\hline & $\mathbf{W}$ & 1765 & 1902 & 1868 & 1846 & 1957 & 2027 & $14.84 \%$ \\
\hline \multirow[t]{9}{*}{ Industry } & Total & 61260 & 58853 & 53448 & 49715 & 51077 & 52233 & $-14.74 \%$ \\
\hline & NW & 9837 & 9329 & 8483 & 7988 & 8284 & 8572 & $-12.86 \%$ \\
\hline & $\mathrm{C}$ & 9610 & 9057 & 8190 & 7625 & 7813 & 7905 & $-17.74 \%$ \\
\hline & NE & 7795 & 7511 & 6791 & 6283 & 6421 & 6423 & $-17.60 \%$ \\
\hline & SE & 6697 & 6659 & 6051 & 5653 & 5808 & 5975 & $-10.78 \%$ \\
\hline & $\mathbf{S}$ & 6763 & 6505 & 5921 & 5464 & 5572 & 5746 & $-15.04 \%$ \\
\hline & BI & 10007 & 9578 & 8769 & 8071 & 8267 & 8525 & $-14.81 \%$ \\
\hline & SW & 4322 & 4271 & 3866 & 3641 & 3793 & 3833 & $-11.31 \%$ \\
\hline & $\mathbf{W}$ & 6229 & 5943 & 5377 & 4990 & 5119 & 5254 & $-15.65 \%$ \\
\hline \multirow[t]{9}{*}{ Constructions } & Total & 59389 & 60135 & 49348 & 43503 & 44607 & 45382 & $-23.59 \%$ \\
\hline & NW & 10687 & 10589 & 8514 & 7481 & 7755 & 7939 & $-25.71 \%$ \\
\hline & $\mathrm{C}$ & 7705 & 7767 & 6250 & 5434 & 5517 & 5640 & $-26.80 \%$ \\
\hline & NE & 6047 & 6164 & 5075 & 4534 & 4642 & 4803 & $-20.57 \%$ \\
\hline & SE & 6019 & 6283 & 4932 & 4366 & 4422 & 4459 & $-25.92 \%$ \\
\hline & $\mathbf{S}$ & 6621 & 6871 & 5671 & 4949 & 5029 & 5040 & $-23.88 \%$ \\
\hline & BI & 13245 & 13339 & 11385 & 10043 & 10290 & 10453 & $-21.08 \%$ \\
\hline & SW & 3455 & 3597 & 3071 & 2733 & 2850 & 2856 & $-17.34 \%$ \\
\hline & $\mathbf{W}$ & 5610 & 5525 & 4450 & 3963 & 4102 & 4192 & $-25.28 \%$ \\
\hline \multirow[t]{9}{*}{ Trade } & Total & 214137 & 197611 & 181903 & 165100 & 169723 & 171259 & $-20.02 \%$ \\
\hline & NW & 27356 & 24755 & 22529 & 20472 & 21192 & 21545 & $-21.24 \%$ \\
\hline & $\mathrm{C}$ & 23768 & 21865 & 19972 & 18113 & 18405 & 18487 & $-22.22 \%$ \\
\hline & NE & 26063 & 23580 & 21431 & 19340 & 19672 & 19723 & $-24.33 \%$ \\
\hline & SE & 29090 & 26381 & 24391 & 21684 & 22130 & 22115 & $-23.98 \%$ \\
\hline & $\mathbf{S}$ & 26441 & 24498 & 22664 & 20583 & 20977 & 21094 & $-20.22 \%$ \\
\hline & BI & 43619 & 41827 & 39011 & 36065 & 37714 & 38782 & $-11.09 \%$ \\
\hline & SW & 18974 & 17357 & 16180 & 14678 & 15072 & 14907 & $-21.43 \%$ \\
\hline & $\mathbf{W}$ & 18826 & 17348 & 15725 & 14165 & 14561 & 14606 & $-22.42 \%$ \\
\hline \multirow[t]{9}{*}{ Services } & Total & 206579 & 209985 & 191866 & 178540 & 190700 & 199450 & $-3.45 \%$ \\
\hline & NW & 29152 & 29285 & 26447 & 24578 & 26527 & 28007 & $-3.93 \%$ \\
\hline & C & 25188 & 25380 & 22919 & 21242 & 22316 & 23128 & $-8.18 \%$ \\
\hline & NE & 19154 & 19740 & 17846 & 16430 & 17464 & 18297 & $-4.47 \%$ \\
\hline & SE & 21341 & 22038 & 20106 & 18740 & 19874 & 20684 & $-3.08 \%$ \\
\hline & $\mathbf{S}$ & 17288 & 17740 & 16698 & 15847 & 17118 & 18038 & $4.34 \%$ \\
\hline & BI & 62269 & 62782 & 57666 & 53747 & 57635 & 60122 & $-3.45 \%$ \\
\hline & SW & 11996 & 12557 & 11634 & 11016 & 11821 & 12377 & $3.18 \%$ \\
\hline & $\mathbf{W}$ & 20191 & 20463 & 18550 & 16940 & 17945 & 18797 & $-6.90 \%$ \\
\hline
\end{tabular}

Source: Processed by the author based on TEMPO-ONLINE data 
The constructions and trade registered decrease in value of the ratio of companies which operate in the regions. Explanations are given mainly by the dramatic decrease of the population's income in the immediate period following the outbreak of the economic and financial crisis. Practically, in the period 2008-2013 a reorientation of the economic operators towards the services and agricultural sector took place.

In the Southeast region, in 2013 , only $7.92 \%$ of the companies operated in the constructions sector, in contrast to $11.64 \%$ in the Northwest region. The South Oltenia region shows the highest figure of the trade sector $(42.16 \%$ in 2013), while the Northwest region the lowest value (31.59\% in 2013).

Table 4: Active enterprises by sectors and regions 2008-2013 (\% in total region)

\begin{tabular}{|c|c|c|c|c|c|c|c|c|c|c|c|c|c|c|c|}
\hline \multirow[t]{2}{*}{ Region } & \multicolumn{5}{|c|}{$2008(\%$ in total $)$} & \multicolumn{5}{|c|}{2013 (\% in total) } & \multicolumn{5}{|c|}{$\pm \Delta 2013 / 2008(\%)$} \\
\hline & 1 & 2 & 3 & 4 & 5 & 1 & 2 & 3 & 4 & 5 & 1 & 2 & 3 & 4 & 5 \\
\hline North-West & 2.18 & 12.49 & 13.57 & 34.74 & 37.02 & 3.14 & 12.57 & 11.64 & 31.59 & 41.06 & 0.96 & 0.08 & -1.93 & -3.15 & 4.04 \\
\hline Center & 14.13 & 14.13 & 11.33 & 34.95 & 37.04 & 3.64 & 13.81 & 9.85 & 32.29 & 40.40 & -10.49 & -0.32 & $-1,48$ & -2.66 & 3.36 \\
\hline North-East & 3.02 & 12.80 & 9.93 & 42.80 & 31.45 & 4.18 & 12.50 & 9.35 & 38.38 & 35.60 & 1.16 & -0.30 & -0.58 & -4.42 & 4.15 \\
\hline South-East & 3.59 & 10.23 & 9.19 & 44.42 & 32.58 & 5.43 & 10.61 & 7.92 & 39.29 & 36.74 & 1.85 & 0.39 & -1.27 & -5.13 & 4.16 \\
\hline South & 3.98 & 11.37 & 11.13 & 44.45 & 29.06 & 5.62 & 10.86 & 9.53 & 39.88 & 34.10 & 1.64 & -0.51 & -1.60 & -4.57 & 5.04 \\
\hline Bucuresti-Ilfoy & 0.62 & 7.70 & 10.19 & 33.57 & 47.92 & 0.79 & 7.17 & 8.80 & 32.64 & 50.60 & 0.17 & -0.53 & $-1,40$ & -0.93 & 2.68 \\
\hline South-West & 2.60 & 10.86 & 8.69 & 47.70 & 30.16 & 3.92 & 10.84 & 8.08 & 42.16 & 35.00 & 1.33 & -0.02 & $-0,61$ & -5.54 & 4.85 \\
\hline West & 3.35 & 11.84 & 10.66 & 35.78 & 38.37 & 4.52 & 11.71 & 9.34 & 32.55 & 41.89 & 1.16 & -0.13 & -1.32 & -3.23 & 3.52 \\
\hline
\end{tabular}

Legend: 1 - Agriculture; 2 - Industry; 3 - Constructions; 4 - Trade; 5 - Services Source: Own calculations based on TEMPO-ONLINE data

\subsection{Activity ratio}

To estimate the level of activity ratio we chose to calculate its variability indicators by total and by genders. The evolution of discrepancies can be observed in figure 5 .

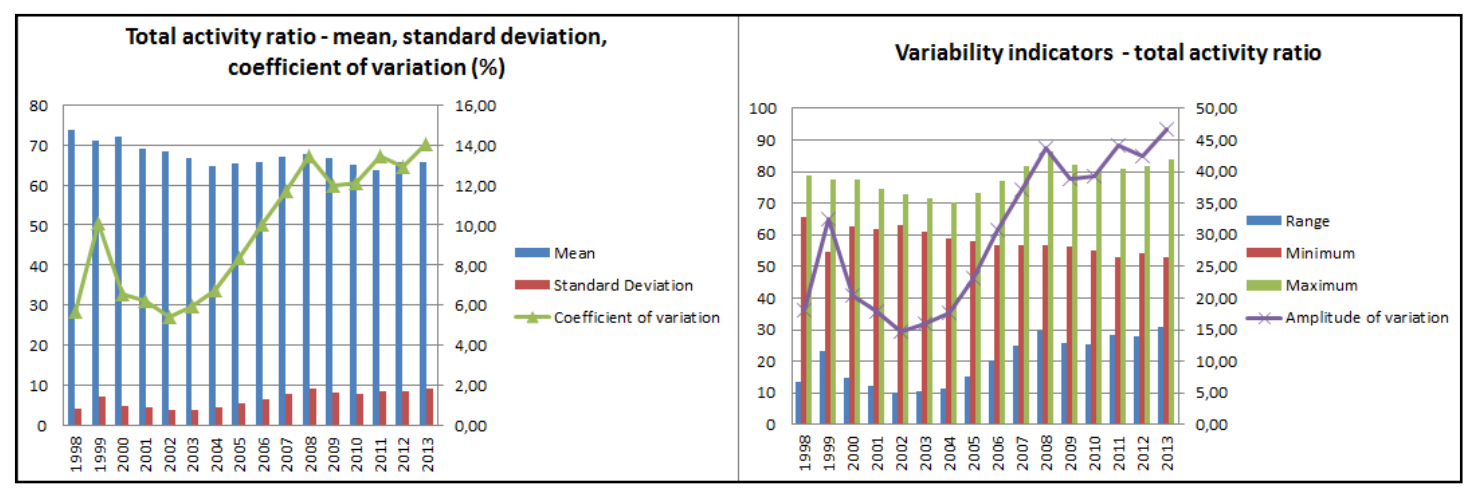

Figure 5: Variability indicators - total activity ratio

Source: Own calculations based on TEMPO-ONLINE data

With small exceptions, we observe a downward trend of standard deviation until 2004. In the last part of the analysed period the standard deviation was growing which implicitly meant a growth of the regional disparities in terms of activity ratio. The highest regional disparity was registered in 2013 (9.22\% standard deviation). Similarly, the increase at regional level of the amplitude of the activity ratio can be noticed. The greatest differences between the maximum and minimum values of the activity ratio are over 30\% (in 2013, the difference between the Bucharest-Ilfov region$83.8 \%$ and Northeast region-53.1\%).

From the point of view of interregional disparities, the indices (fig. 6) represent decrease for the interval 1999-2013 for certain regions (Northeast, Southeast, South-Muntenia regions). For other regions, however, fluctuating trends can be noticed. In contract to the rest of the regions, BI region moved away. Starting from 2007 it registered values over $120 \%$. The NE and SE regions register values under the national level during the entire period. Other regions such as Northwest, Central and West reach values over the national average. Gaps between maximum and minimum values related to the first and last years of the period are 1.2:1 (between Northwest and BI regions-1998) and 1.58:1 (between 


\section{Nela Steliac}

The Labor Market in Romania and Interregional Disparities

BI and Northeast regions). Similarly, noteworthy is the fact that between 1998 and 2001, BI is the region with the lowest level of activity ratio, while in 2013 it registered the highest level.

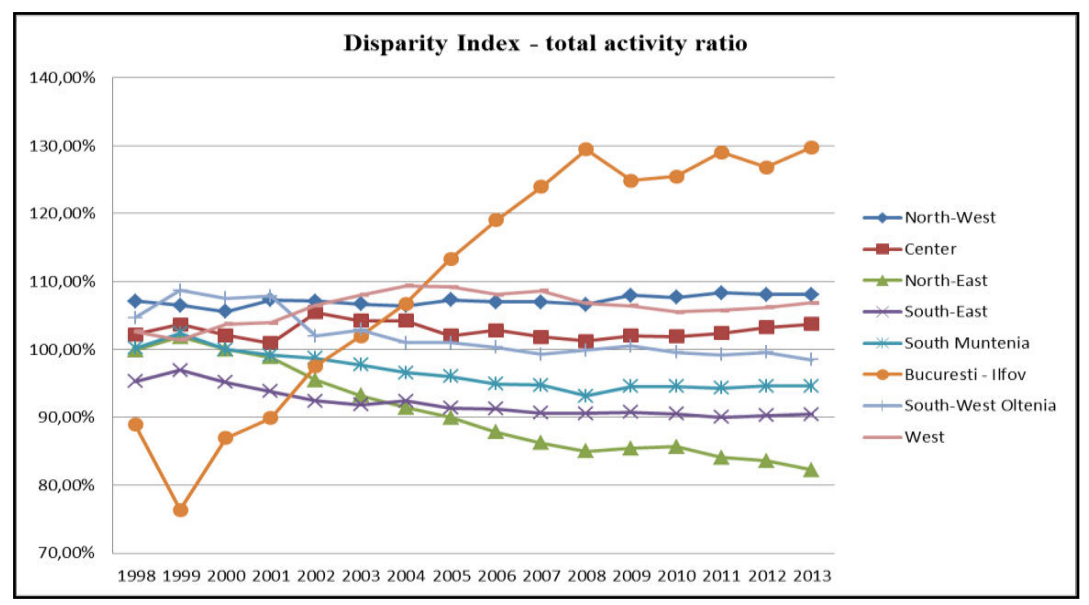

Figure 6: Disparity index - total activity ratio

Source: Own calculations based on TEMPO-ONLINE data

The same evolutionary line had the interregional disparities of the male and female activity ratio. There are, however, some differences concerning the minimum and maximum values and the variation amplitude (see fig. 7-8).

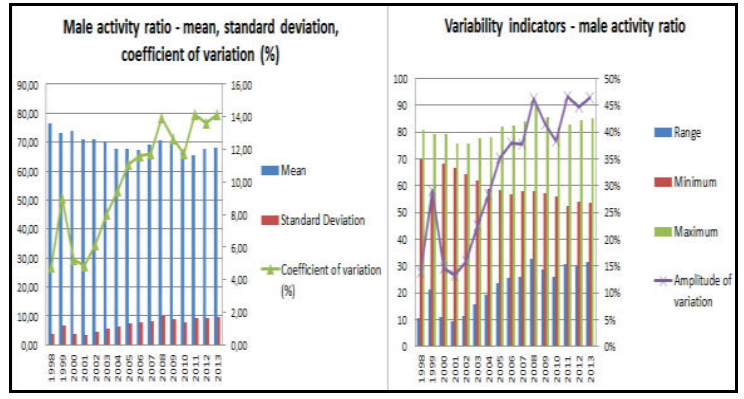

Fig. 7 Variability indicators - male activity ratio

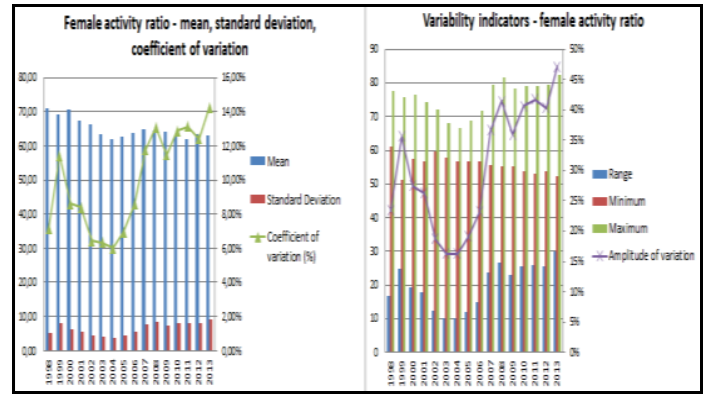

Fig. 8 Variability indicators - female activity ratio

Source: Own calculations based on TEMPO-ONLINE data

\subsection{Average number of employees}

The average number of employees dropped with 925,119 persons in 2013 compared to 1998. This decrease was generated both by national, sectorial and regional factors. Their influences are shown in the table below:

Table 5: Shift-Share analysis by regions - number of employees (persons)

\begin{tabular}{|c|c|c|c|c|}
\hline \multirow[t]{2}{*}{ Region } & \multicolumn{3}{|c|}{ Breakdown by factor of the absolute change of population employment: } & \multirow{2}{*}{$\begin{array}{c}\text { Absolute change of } \\
\text { population } \\
\text { employment } \\
2013 / 1998(\Delta E R)\end{array}$} \\
\hline & $\begin{array}{c}\text { National component } \\
(\mathrm{Nr})\end{array}$ & $\begin{array}{c}\text { Sectorial component } \\
(\mathbf{S r})\end{array}$ & $\begin{array}{l}\text { regional component } \\
\text { (Rr) }\end{array}$ & \\
\hline North-West & $-118,017$ & $-5,049$ & 29,443 & $-93,624$ \\
\hline Center & $-121,843$ & $-20,506$ & 9,074 & $-133,275$ \\
\hline North-East & $-125,147$ & 1,772 & $-104,953$ & $-228,327$ \\
\hline South-East & $-114,614$ & 947 & $-52,506$ & $-166,174$ \\
\hline South & $-128,191$ & $-29,434$ & $-58,225$ & $-215,850$ \\
\hline Bucharest-Ilfov & $-134,756$ & 56,588 & 211,692 & 133,525 \\
\hline South-West & $-85,785$ & $-1,747$ & $-48,505$ & $-136,037$ \\
\hline West & $-96,766$ & $-2,571$ & 13,980 & $-85,357$ \\
\hline
\end{tabular}

Source: Own calculations based on TEMPO-Online data 
According to the data included in the table above, except for BI region, decrease in the number of employment took place all over the places. The highest decrease was registered in the case of NE region, over 228 thousand persons, while the lowest decrease in West region, 85,357 persons. The national component affected negatively the number of employees in every region. The most significant decrease was registered in BI region. The sectorial component influenced negatively five regions (NW, C, S, SW and W), while NE, SE and BI regions registered increase of employees as a result of the influence of sectorial factors. NW, C, BI and W regions show regional advantages thus determining growth in the number of employees. As is can be noticed as well in the results of the Shift-Share analysis, BI region significantly moves away both in terms of sector and region.

The interregional disparities in terms of average number of employees can be noted based as well on variability indicators.

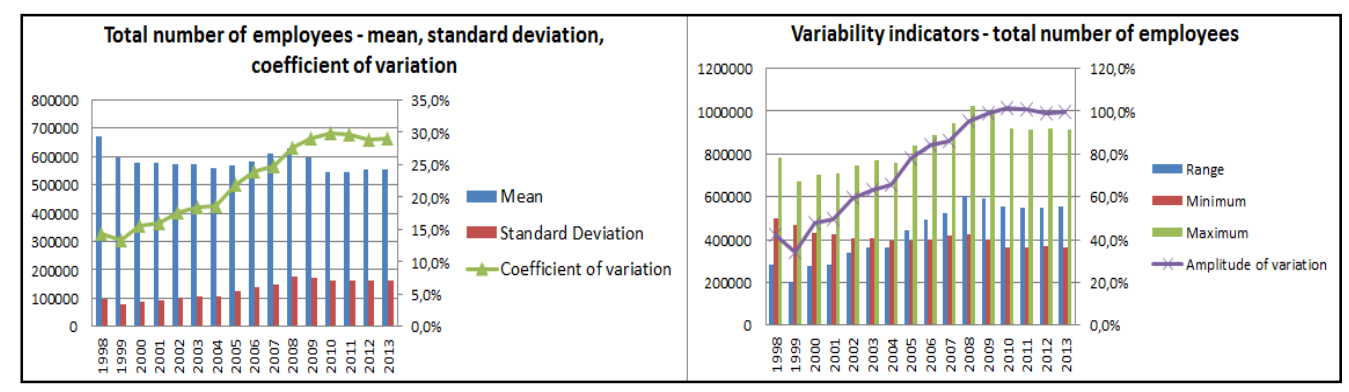

Figure 9: Variability indicators - total number of employees

Source: Own calculations based on TEMPO-Online data

The chart above indicates the fluctuating trend of the indicator (both by the average value and by the maximum and minimum value). In general, between 1998 and 2008 the standard deviation was increasing, which meant a downward trend of regional convergence in terms of number of employees. After 2008, a relatively insignificant growth of convergence was registered. The regional poles in terms of number of employees were Southwest Oltenia (the lowest number) and BI (the highest number) region. The gaps between these ranged from 1.33 in 1999 (the lowest) to 2.53 (the highest). The evolution of these gaps was increasing.

Based on the analysis of the variability indicator of the average number of employees by the five sectors (agriculture, industry, constructions, trade and services) we can state that:

- Southwest Oltenia region registered the lowest values of this indicator in the entire period for the sectors: industry, trade and services. This is, in fact, the region with the lowest total number of employees;

- BI region has the highest number of employees in the fields: constructions, trade and services. At the same time this is the region with the lowest number of employees in the agricultural sector. Such a situation can be explained as a result of the extremely reduced agricultural land compared to other regions;

- South Muntenia region, a region considered as well being predominantly agricultural, registered the highest number of employees in the field of agriculture;

- Regarding the interregional disparities of the number of employees by sectors the following aspects must also be mentioned:

- In agriculture, with small exceptions $(2009,2012)$, the regional disparities gradually decreased (increase of regional convergence took place (see fig. 10). The regional poles were South Muntenia (for maximum) and BI (for minimum) regions;

- The phenomenon of increase of regional convergence can be noted as well in the case of the industrial sector, however, in some intervals of the studied period. The standard deviation decreases between 1998 and 2000, 2001-2006, 2008-2009. For the rest of the years analysed, a downward trend of the regional convergence was found (increase of disparities) (fig.11). The regional poles were the Central (for maximum) and Southwest Oltenia (for minimum) regions;

- In the case of constructions, the periods between 1999-2005, and 2006-2009, respectively, are characterized by growing regional disparities. The regional convergence increases, however, between 2009 and 2012 
(fig.12). The regional poles were BI (for maximum) and Southwest Oltenia regions (between 2002-2013), West region between 1998-2001 (for minimum), respectively;

- Growing interregional disparities are found as well in the case of the average number of employees in the trade sector. This took place until 2008. Following this year, however, a relatively insignificant increase of convergence took place (fig.13). The regional poles were BI (for maximum) and Southwest Oltenia (for minimum) regions;

- The services sector was as well characterised, in general, by increase of interregional disparities, an aspect revealed as well by the evolution of standard deviation (fig.14). The regional poles were BI (for maximum) and Southwest Oltenia (for minimum) regions.

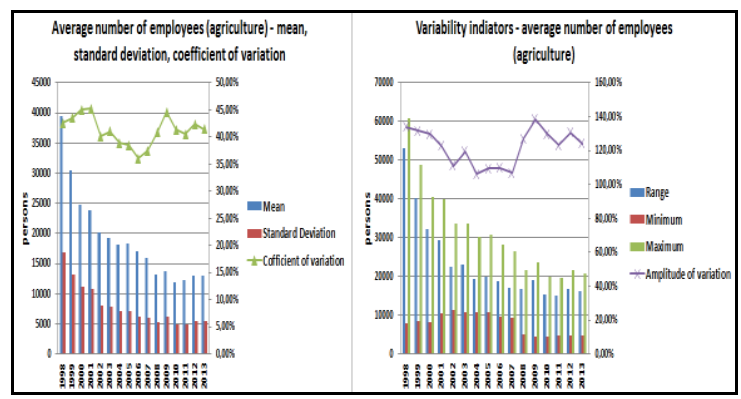

Fig. 10 Variability indicators - average number of employees - agriculture

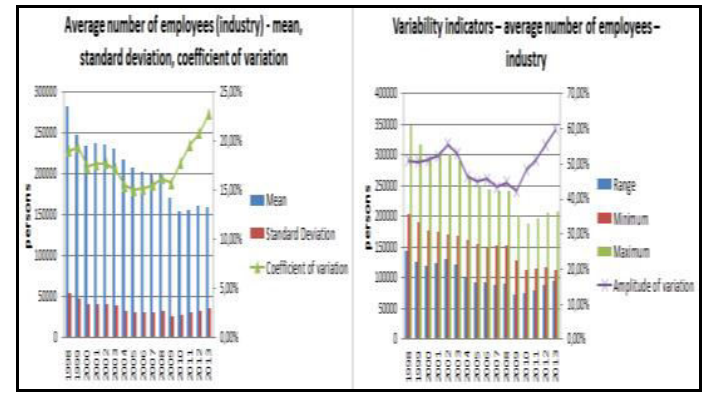

Fig. 11 Variability indicators - average number of employees - industry

Source: Own calculations based on TEMPO-Online data

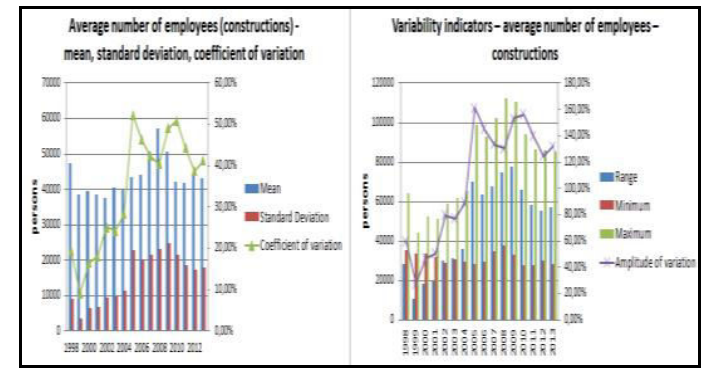

Fig. 12 Variability indicators - average number of employees - constructions

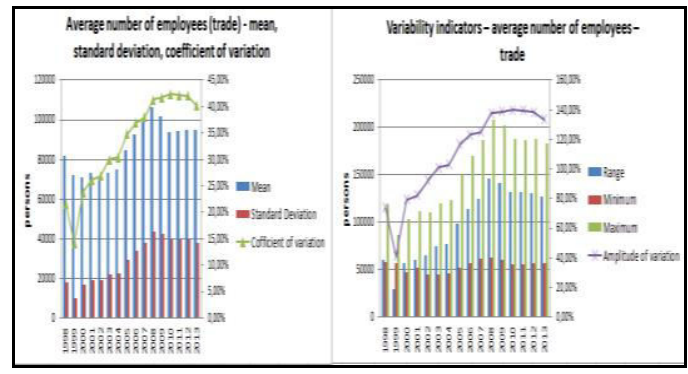

Fig. 13 Variability indicators - average number of employees - trade

Source: Own calculations based on TEMPO-Online data

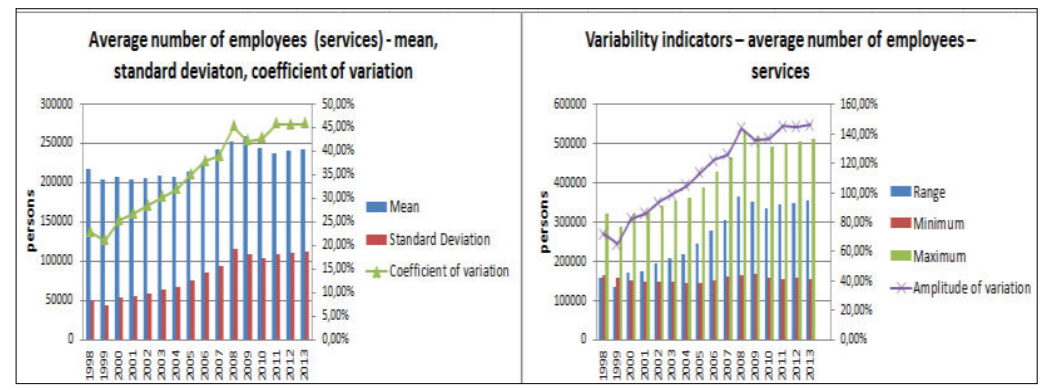

Figure 14: Variability indicators - average number of employees - services Source: Own calculations based on TEMPO-Online data

Distribution of employees by the five sectors within the regions is according to fig. 15. This allows us to point out the following aspects:

- The preponderance of employees in the services sector, especially in the last part of the period studied (just as in the case of population employment), at a significant difference compared to the industrial sector for the majority of the regions (Northwest region, Northeast region, Southeast region, Southwest region, South-Muntenia and Bucharest-Ilfov region); 
- Employees massive orientation towards the field of services in the case of Bucharest-Ilfov region and limitation of weight in the industrial sector (specialization of region in the field of services-over 55\% of the employees in 2013);

- Specialization of the Central and West region in the field of industry;

- $\quad$ Significant limitation of industrial activity in certain regions (NE, BI);
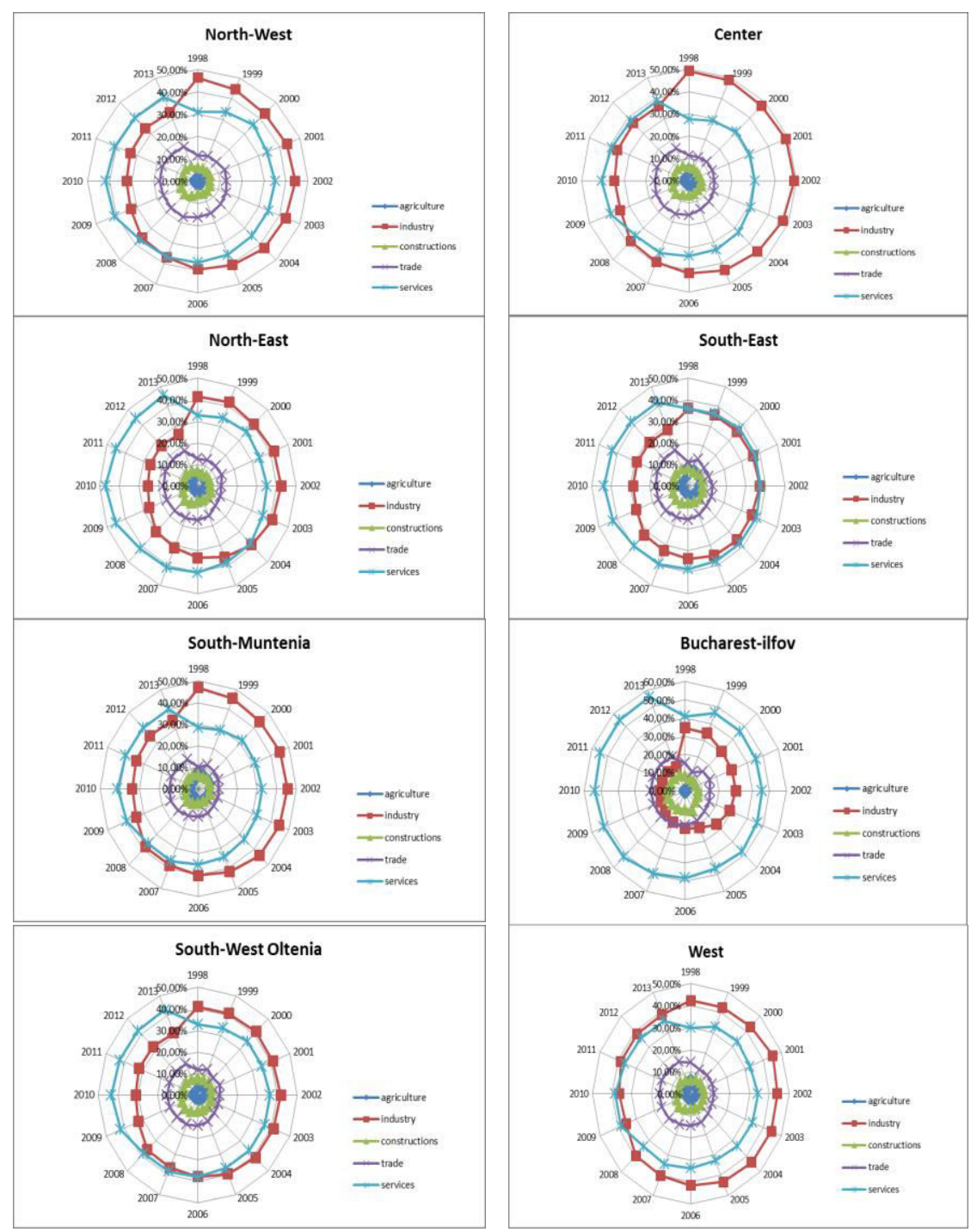

Figure 15: Distribution of employees by sectors and regions

Source: Calculations and charts drawn up by the author based on TEMPO-ONLINE data

If we call into question the regional concentration level of the average number of employees in the five sectors, then we can say that there is no such regional concentration. The value of Gini-Struck coefficient is lower than 0.3 , which allows us to state that there is no significant level of regional concentration of employees. Nonetheless, we must point out the fact that it registered an upward trend in the entire period studied, in the case of every sector. The most significant values belong to the services sector, and the lowest values correspond to the industrial sector. 


\section{Nela Steliac}

The Labor Market in Romania and Interregional Disparities

Table 6: GINI-STRUCK coefficient - employees by sectors

\begin{tabular}{|c|c|c|c|c|c|}
\hline Year & Agriculture & Industry & Construction & Trade & Services \\
\hline 1998 & 0.1507 & 0.0674 & 0.0685 & 0.0766 & 0.0805 \\
\hline 1999 & 0.1539 & 0.0688 & 0.0323 & 0.0500 & 0.0743 \\
\hline 2000 & 0.1591 & 0,0616 & 0.0586 & 0.0840 & 0.0898 \\
\hline 2001 & 0.1600 & 0.0626 & 0.0639 & 0.0924 & 0.0947 \\
\hline 2002 & 0.1418 & 0.0629 & 0.0887 & 0.0951 & 0.1004 \\
\hline 2003 & 0.1452 & 0.0609 & 0.0860 & 0.1060 & 0.1067 \\
\hline 2004 & 0.1377 & 0.0548 & 0.1004 & 0.1077 & 0.1130 \\
\hline 2005 & 0.1362 & 0.0533 & 0.1851 & 0.1229 & 0.1237 \\
\hline 2006 & 0.1274 & 0.0540 & 0.1636 & 0.1306 & 0.1340 \\
\hline 2007 & 0.1324 & 0.0551 & 0.1497 & 0.1345 & 0.1381 \\
\hline 2008 & 0.1444 & 0.0576 & 0.1428 & 0.1460 & 0.1603 \\
\hline 2009 & 0.1577 & 0.0558 & 0,1738 & 0.1476 & 0.1493 \\
\hline 2010 & 0.1463 & 0.0632 & 0,1799 & 0.1499 & 0.1512 \\
\hline 2011 & 0.1433 & 0.0695 & 0,1567 & 0.1491 & 0.1620 \\
\hline 2012 & 0.1497 & 0.0737 & 0,1372 & 0.1488 & 0.1619 \\
\hline 2013 & 0.1466 & 0.08063 & 0,1460 & 0.1418 & 0.1624 \\
\hline
\end{tabular}

Source: Own calculations based on TEMPO-Online data

\subsection{Job vacancy rate}

In case of job vacancy rate the period analysed included years 2005-2013, explained by the lack of statistical data. Fluctuating evolution of the rate (average, minimum and maximum values) can be noticed. Until 2008 inclusively, the regional convergence shows a decrease and increase the following 4 years. The last 2 years are characterized by the increase of interregional discrepancies from the perspective of job vacancies in economy. The regional poles are different from one year to the other. In general, these are the following: Southwest Oltenia, Northwest, and Southeast (for the lowest rates of job vacancies) regions and for the highest rates: BI and Northeast, West (in some years).

In terms of disparity index we can notice the same regional discrepancies. All regions show fluctuating evolutions. Nonetheless, there are regions of which disparity index exceed, in general, 100\% (BI, Northeast, West, South Muntenia), and others with values under 100\% (Southwest Oltenia, Central, Northwest, Southeast). Extreme values are registered in 2010: 52.54\% (Southeast region) and 179.66\% (Northeast region).

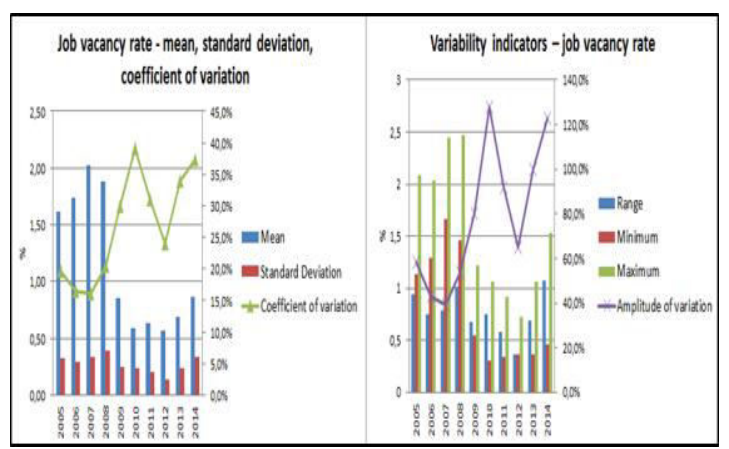

Fig. 16 Variability indicators - job vacancy rate

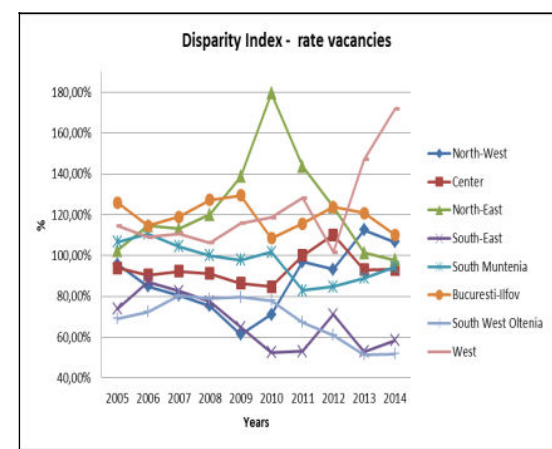

Fig. 17 Disparity index - compared to the national average $(=100)$

Source: Own calculations based on TEMPO-Online data

At the same time, the interregional differences in terms of job vacancies can be highlighted as well in the chart below: 


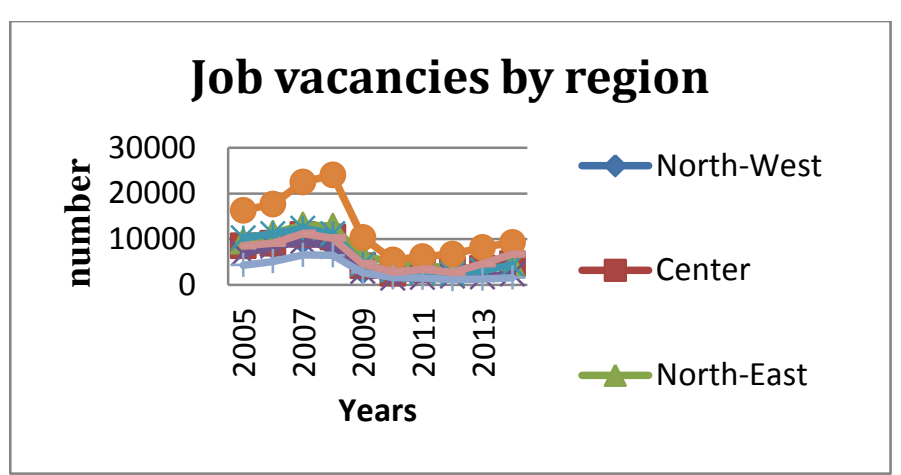

Figure 18: Job vacancies by regions (2005-2014)

Source: Chart drawn up by the author based on TEMPO-ONLINE data

As it can be noted, BI region significantly moves away from the rest of the regions in terms of the total number of job vacancies. At the opposite pole we find SW Oltenia region. The ratio between the two poles increased from 3.76:1 in 2005 to $5.82: 1$ in 2014 .

The job vacancies were distributed by the three sectors according to the data in the table below:

Table 7: Job vacancies by sectors (2005-2013)

\begin{tabular}{|c|c|c|r|r|r|r|r|r|r|r|}
\hline Sectors & $\mathbf{2 0 0 5}$ & $\mathbf{2 0 0 6}$ & $\mathbf{2 0 0 7}$ & $\mathbf{2 0 0 8}$ & $\mathbf{2 0 0 9}$ & $\mathbf{2 0 1 0}$ & $\mathbf{2 0 1 1}$ & $\mathbf{2 0 1 2}$ & $\mathbf{2 0 1 3}$ & $\mathbf{2 0 1 4}$ \\
\hline $\begin{array}{c}\text { Agri- } \\
\text { culture }\end{array}$ & 2,593 & 2,507 & 2,489 & 1,585 & 1,126 & 629 & 618 & 273 & 299 & 382 \\
\hline $\begin{array}{c}\text { Industry } \\
\text { \& con- } \\
\text { structions }\end{array}$ & 30,677 & 29,955 & 34,332 & 29,594 & 10,396 & 9,445 & 11,025 & 9,879 & 11,751 & 12,860 \\
\hline Services & 40,118 & 48,095 & 59,151 & 61,043 & 27,103 & 14,165 & 14,414 & 14,673 & 18,593 & 25,281 \\
\hline Total & 73,380 & 80,557 & 95,972 & 92,222 & 38,625 & 24,239 & 26,057 & 24,825 & 30,643 & 38,523 \\
\hline
\end{tabular}

Source: Own calculations based on TEMPO-Online data

We note that the peak economic years ensured the most job vacancies, up to approximately 96,000 jobs. Most of them were offered in the services sector and the fewest in the agricultural sector.

The situation by regions and sectors of job vacancies was according to fig. 19. In agriculture the most job vacancies were offered until 2009 inclusively, in the Central region, and then the most jobs were offered in Northeast region. In the industry and constructions sector Northwest, Northeast, Bucharest-Ilfov or West regions dominated successively. The fewest jobs in this sector were found in South West Oltenia region. Taken as a whole, services dominated the job vacancy market. By regions, Bucharest-Ilfov significantly moved away from the rest, and in some years, at national level offered approximately $1 / 3$ of the total job vacancies in services and sometimes even up to approximately $38 \%$ (in 2012) of this total.

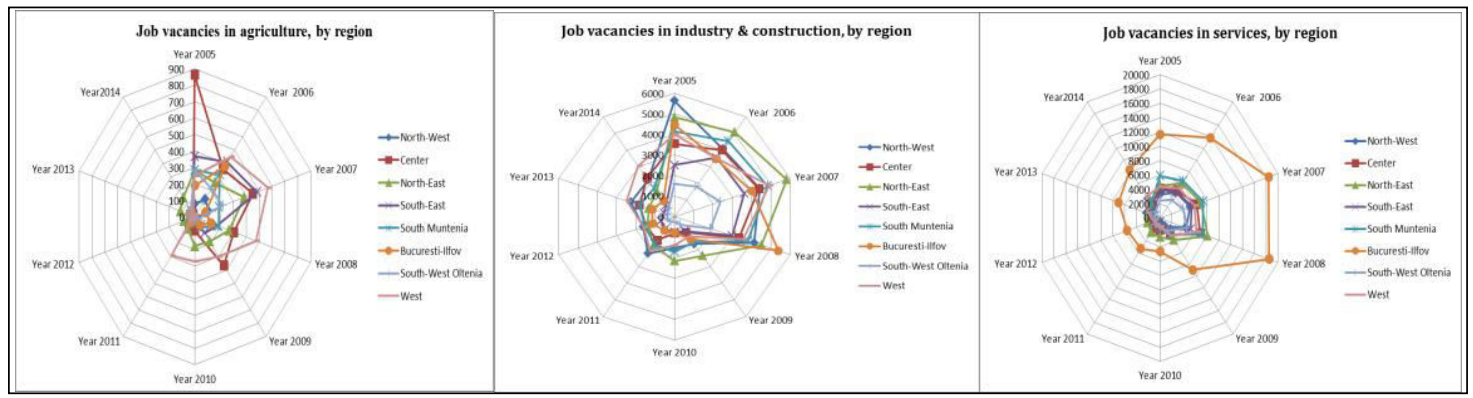

Figure 19: Job vacancies by sectors and regions

Source: Calculations and charts drawn up by the author based on TEMPO-ONLINE data 


\subsection{Unemployment rate}

According to fig. 20, except for the year 2002, until 2007, inclusively, we talk about a decrease of the interregional disparities in terms of unemployment rate. 2008 and 2009 mark, however, an increase of standard deviation (decrease of regional convergence), in the next two years a new decrease is registered, while in the last two years we identify an insignificant increase of dispersion. The same fluctuating evolution was registered as well in terms of the average value of the unemployment rate. Significant decrease is observed between 1999 and 2007 , from $10.14 \%$ to $4.05 \%$. In the last part of the period, the highest rate is registered in 2009 , that is, $7.86 \%$. In terms of extreme values, per overall period, the lowest value of the unemployment rate was of 1.7\% (2007), registered in Bucharest-Ilfov region, while the highest value was reported in 1999 in Northeast region, that is, of 14.9\%. As expected, Bucharest-Ilfov region constantly reported the lowest values for this indicator. Concerning the maximum value, until 2004, Northeast region registered the maximum value, and starting from 2005, its place was taken by Southwest Oltenia region.

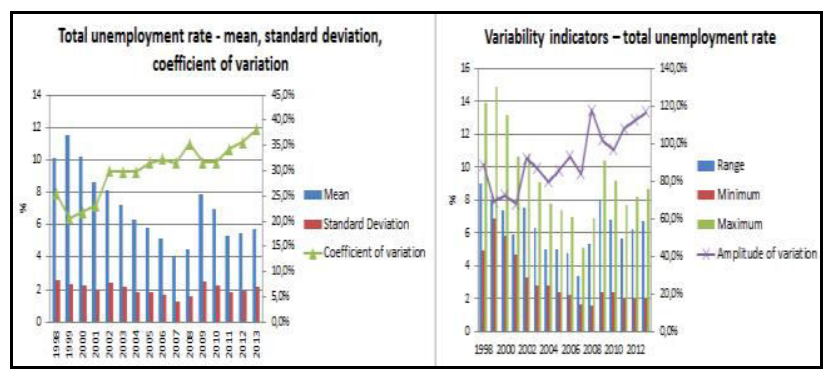

Fig. 20 Variability indicators- total unemployment rate

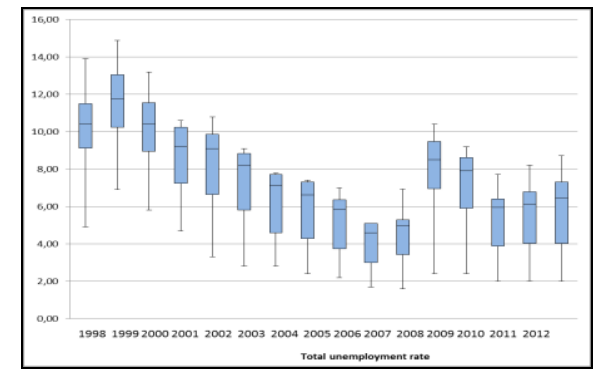

Fig. 21 Box plots for total unemployment rate

Source: Calculations and charts drawn up by the author based on TEMPO-ONLINE data

Compared to the national average, 2 regions had constantly an index higher than $100 \%$ (NE, and S regions), 2 regions (NW and BI regions) had constantly values lower than 100\%, and the rest of the regions (C, S and W) reported either lower values, or values higher than $100 \%$. The regional poles were BI (for minimum) and NE in the first part of the period and SW Oltenia (for maximum) in the last part.

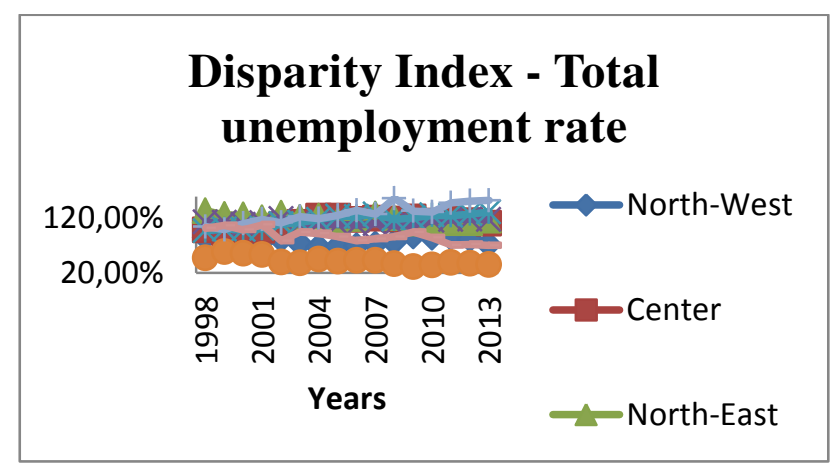

Figure 22: Disparity index - total unemployment rate

Source: Calculations and chart drawn up by the author based on TEMPO-ONLINE data

Interregional disparities of male and female unemployment rate had the same evolutionary line as the total unemployment rate. The year 2007 marks the lowest interregional disparities both for women and men. In terms of male unemployment rate, the interregional disparities were higher than for female unemployment rate. Gender differences were identified in the following cases: minimum and maximum values and variation amplitude (see fig. 2324). 


\section{Nela Steliac}

The Labor Market in Romania and Interregional Disparities

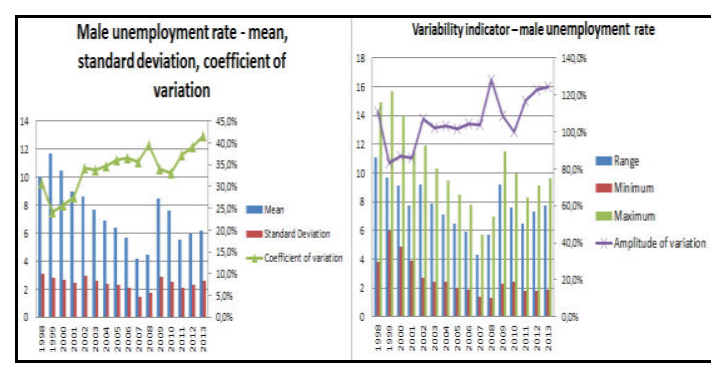

Fig. 23 Variability indicator - male unemployment rate

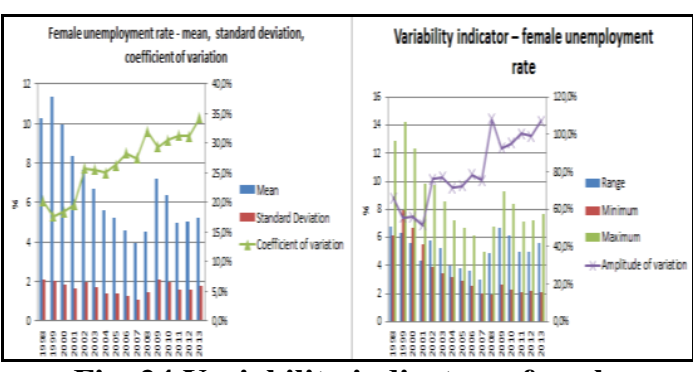

Fig. 24 Variability indicator - female unemployment rate

\section{Source: Own calculations based on TEMPO-ONLINE data}

Regarding the degree of concentration for the total number of male and female unemployed, we cannot talk about significant values. Each coefficient had a value lower than 0.3 , which means that there was no concentration of these by regions. Nonetheless, it must be said that starting from 2009, the values of GINI-STRUCK coefficients followed an upward trend, meaning a slight increase of the degree of regional concentration. Besides, here we also deal with regional poles. No doubt, the minimum level is registered in BI region, both for the total and for female and male. In the case of the total unemployed, the number of female unemployed and the number of male unemployed, either Northeast region or South Muntenia region was ranked first.

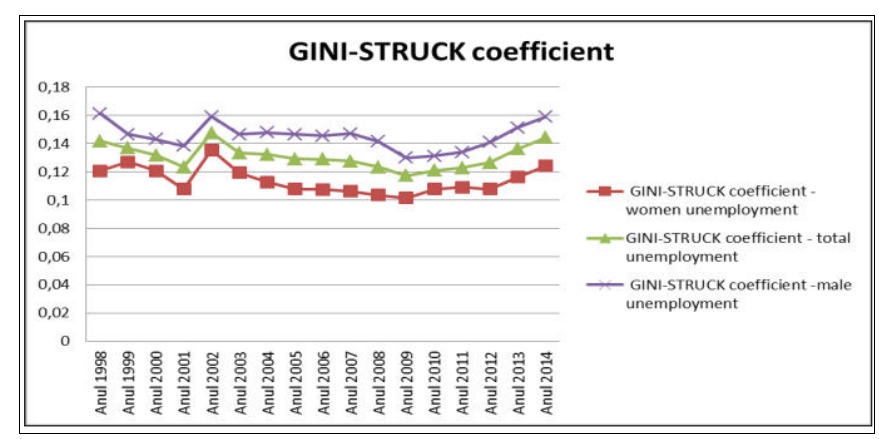

Figure 25: GINI-STRUCK coefficient - total unemployed, male, female

Source: Calculations and chart drawn up by the author based on TEMPO-ONLINE data

\subsection{Average monthly net salary}

For the analysis of regional gaps in terms of average net salary, we used two distinct periods as a result of the different measures of unit, that is, thousand Lei until 2004, and RON starting from 2005.

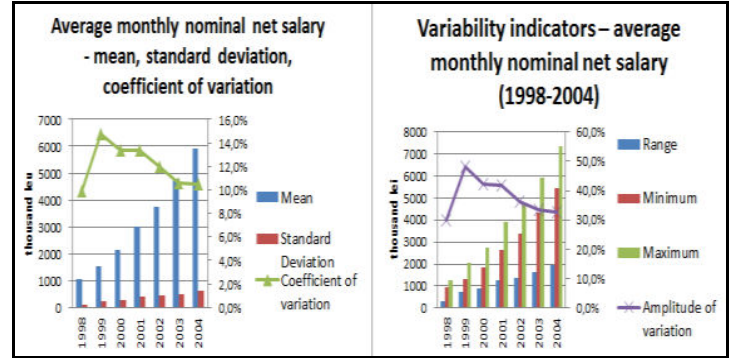

Fig. 26 Variability indicators - average monthly nominal net salary (1998-2004)

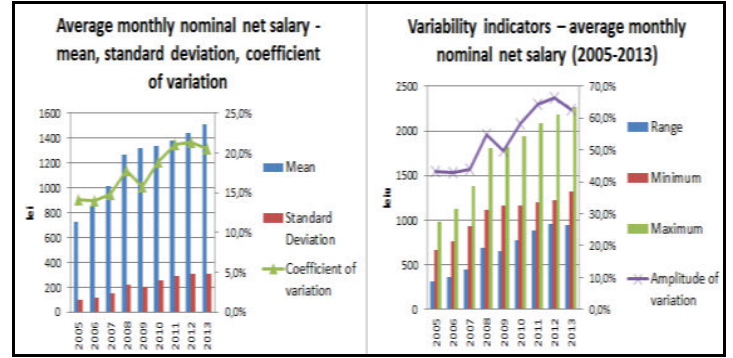

Fig. 27 Variability indicators - average monthly nominal net salary $(2005-2013)$

Source: Own calculations based on TEMPO-ONLINE data

Between 1998 and 2004, the increase of average monthly net salary generated increase in the average values, maximum and minimum of this indicator. The regional convergence, however, decreases (standard deviation is growing). The other terms of variation (minimum, maximum, variability, amplitude) had as well an upward trend, thus, the growth of regional gaps in terms of average net salary income was confirmed. The growth of minimum salary exceeded the 
growth of maximum salary. The regional poles were this time as well BI (maximum) region and NE (minimum) region. The ratio between the lowest value and the highest value achieved the figure 1.55:1 in 1999. In the period 2005-2013, we witness the decrease of regional convergence (standard deviation increases) up until 2008. The year 2009 marks a decrease in interregional disparities, while in the next years the standard deviation registers an upward trend. The regional poles stay basically the same. Only that for the minimum, we talk either about NE region or NW region. The difference between the maximum and minimum value increases, however, up to the value of 1.78:1 in 2012. The increase of the minimum level does not exceed, however, all the time the growth of maximum level.

BI region is the only region of the country which exceeds the national average in terms of average net salary income during the entire period (1998-2013). Other two regions ranked above the national average only in the first period (1998-2004), that is, SE and SW Oltenia region. The rest of the regions registered increase in salary under the national average. The year 2012 brings to the fore the lowest value of the disparity index for the total period, at the level of NE region, that is, $81.55 \%$ of the national average.

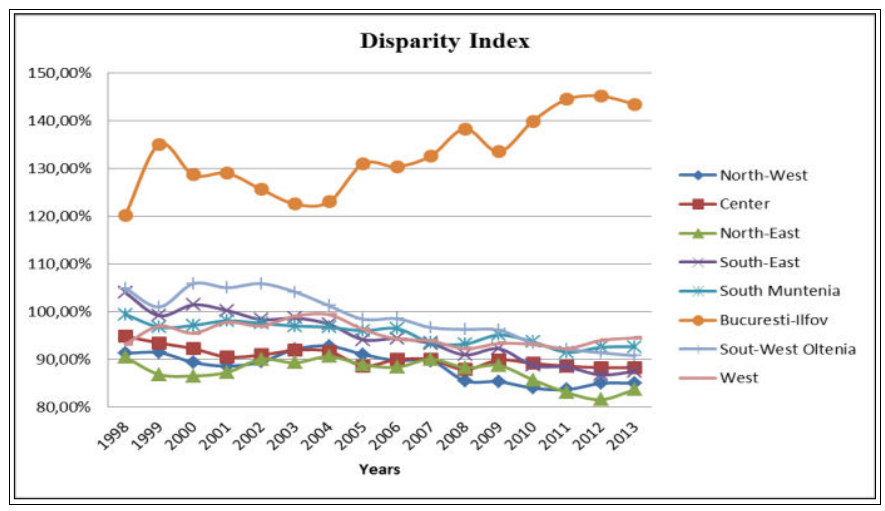

Figure 28: Disparity index - average monthly net salary compared to the national average $(=100)$

Source: Own calculations based on TEMPO-ONLINE data

From the calculations made results the fact that the highest annual percentage increase of the average monthly net salary was registered in BI region. Thus, in the first period, the average monthly net salary was 64\% higher (1999 compared to 1998), while the second period only 31\% (2008 compared to 2007). Further on, in the first period the lowest percentage increase was of approximately 20\% (2004 compared to 2003) in SW region. For the second period we talk, however, about salary decrease of up to $-1.67 \%$ in 2010 compared to the previous year. This is the case of SE region.

\section{Conclusions}

The results of the calculations allow us to conclude that the evolution of regional gaps was in general a sinuous one, marked by decrease and then, by increase. The only indicator at the level of which an upward trend was observed for the entire studied period was the average monthly net salary. What catches attention is, however, the fact that in 2013 the interregional discrepancies were more or less high compared to 1998. As such, we talk in this case about the decrease of regional convergence in the Romanian labor market.

Another aspect which must be pointed out is related to the regional poles. For the best situations, for most of the time, Bucharest-Ilfov region moved away from the rest of the regions. This region occupied in general the best place. There were, however, situations when it ranked at the opposite pole for: population employment and activity ratio. Interesting is also the fact that in the case of population employment, NE region occupied the best place for a long period of time. In the case of the lowest values, however, there were more poles. It is mainly the case of NE region (GDP/inhabitants, activity rate, unemployment rate, average net salary) and SW Oltenia region (number of active enterprises, number of employees, job vacancy rate, and unemployment rate).

We found out, furthermore, the significant orientation of the population employment and the number of employees towards the services sector determining this way changes of the economic profile for some regions. Gini-Struck 
coefficients allowed us to establish that there is no degree of significant concentration on the labor market in Romania. Nevertheless, a slight upward trend in their value was observed.

The results of Shift-Share analysis for population employment and average number of employees pointed out the fact that BI region registered the best evolution in terms of these indicators. Even if the national component influenced negatively their change, the sectorial and regional factors exercised a positive influence. Other regions which benefited from regional advantages apart from BI were NW, C and W.

\section{References}

- Albu, L.L., Ghizdeanu, I., Iordan, M., Ţapu, D.I., 2011. Structura ocupaţională şi reflectarea acesteia în veniturile şi cheltuielile populaţiei din Regiunea Sud-Est - prezent şi perspective, Institutul de Prognoză Economică, Academia Română, Bucureşti, [online] Available at: $<$ http://www.stpse.ro/atasamente/359_Structura\%20ocupationala\%20si\%20reflectarea\%20acesteia\%20in\%20veniturile \%20si\%20cheltuielile\%20populatiei\%20din\%20Regiunea\%20Sud\%20Est.pdf $>$ [Accessed 25 August 2015].

- Antonescu, D., 2010. The Analysis of Regional Disparities in Romania with Gini/Struck Coefficients of Concentration, Romanian Journal of Economics, Institute of National Economy, vol 31, pp.160-183

- Antonescu, D., 2012. Identificarea disparităţilor și convergenței economice regionale în Uniunea Europeana și în România, Revista Studii economice, Academia Română-Institutul Naţional de Cercetări Economice, [online] Available at: <http://www.studii-economice.ro/2012/seince120528.pdf > [Accessed 10 September 2015].

- Antonescu, D., 2013. Politica de dezvoltare regional a României în etapa postaderare, Institutul de Prognoză Economică, Academia Română, Bucureşti, [online] Available at: < http://www.studii-economice.ro/2013/seince130516.pdf > [Accessed 15 August 2015].

- Cârnu, D., 2010. Particularităţi ale dezvoltării regionale şi cauze specific, Analele Universităţii "Constantin Brâncuşi" din Târgu Jiu, Seria Economie, Nr. 3, pp. 75-86.

- Chirilă, V., Chirilă, C., 2014. The impact of economic and financial crisis on the regional disparities in Romania and European Union, Procedia-Social and Behavioral Sciences, 109, pp. 502-506, [online] Available at: < http://www.sciencedirect.com/science/article/pii/S187704281305129X > [Accessed 28 August 2015].

- Diaconu (Maxim), L., 2014. Regional Economic Disparities in Romania. Comparative Analysis of the North-East and West Development Regions, The USV Annals of Economics and Public Administration, vol.14, issue 2920), pp. 75-82.

- Dimian, G.C., 2012. The impact of labor market imbalances on regional disparities in the post-crisis context, Theoretical and Applied Economics, Volume XIX, No. 9(574), pp. 37-48.

- Goschin, Z., et al., 2008. The current state and dynamics of regional disparities in Romania, Romanian Journal of Regional Science, vol. 2, no.2, pp. 80-105

- Goschin, Z., et al., 2010, Impactul regional al crizei economice din perspectiva ocupării forței de muncă, Studii și Cercetări de Calcul Economic și Cibernetică Economică, [online] Available at: <http://www.revcib.ase.ro/bdpdf\%20elsevier/3-4rom\%20pdf/Zizi\%20Goschin.pdf> [Accessed 10 September 2015].

- Jaba, E., 2009. The evaluation of the regional profile of the economic development in Romania, Analele Știintifice ale Universității Alexandru Ioan Cuza" din Iași, Tomul LVI Științe Economice, p. 537-549

- Luţaş, M., Câlea, S., 2005. Economie europeană, Ed. Imprimeria Ardealul, Cluj-Napoca.

- Moisescu, E., R., (2015), Regional convergence. Case of Romania, Theoretical and Applied Economics, Volume XXII, No. 2(603), pp. 183-188

- Nistor, P., 2012. FDI and regional disparities growth in Romania, Procedia Economics and Finance, no. 3, pp. 740 - 745.

- Orboi, M.D., Băneș, A., 2012. The Evolution of the Labour Market in Romania's South-East Region, Scientific Papers: Animal Science and Biotechnologies, 45(1), [online] Available at: < http://www.usabtm.ro/utilizatori/ZOOTEHNIE/file/simpozion\%202012/Vol\%201/Management/Dora.pdf $>$ [Accessed 10 September 2015].

- Parlamentul European. (2016). Parlamentul European. [online] Available at: <http://www.europarl.europa.eu/portal/ro > [Accessed 1 Jul. 2015].

- Pecican, E. Ş., 2009. Indicatori privind convergenţa reală şi aplicaţiile acestora, [online] Available at: $<\mathrm{ftp} / / / \mathrm{ftp}$.repec.org/opt/ReDIF/RePEc/ror/ror_pdf/seince091004.pdf> [Accessed 1 September 2015].

- Pintilescu, C., 2011. Regional economic disparities in Romania, Recent Researches in Applied Economics, [online] Available at: <http://www.wseas.us/e-library/conferences/2011/Iasi/AEBD/AEBD-06.pdf S1877042813052774 > [Accessed 1 September 2015].

- Rotaru, P.C., 2014, Empirical study on regional employment rate in Romania, Procedia - Social and Behavioral Sciences 109, pp. 1365-1369, [online] Available at: < http://www.sciencedirect.com/science/article/pii/S1877042813052774 > [Accessed 15 September 2015]. 
- Russu, C., 2014. Aspects of Regional Development in Romania, Economic Insights - trends and Challenges, Vol.III (LXVI) No. 4/2014, pp. 25-32

- Săvoiu, G., Crăciuneanu, V., Țaicu, M., 2010. A new method of statistical analysis of markets' concentration or diversification, Revista Română de Statistică nr. 2, [online] Available at: $<$ http://www.revistadestatistica.ro/Articole/2010/A3en_2-2010.pdf> [Accessed 1 September 2015].

- Simionescu, M., 2014. The Beta-convergence Analysis and Regional Disparities in EU-28, ACTA VŠFS, 2/2014, vol. 8, p.167-177, [online] Available at: < http://www.vsfs.cz/periodika/acta-2014-02.pdf > [Accessed 17 September 2015].

- Stanef, M.R., 2014. Economic disparities between urban and rural Romanian labor market, Theoretical and Applied Economics, Volume XXI, No. 9(598), pp. 61-70

- Zaman Gh., Vasile V., Matei M, Croitoru C., Enescu G., 2011. Aspecte ale impactului ISD din România asupra exporturilor si dezvoltarii durabile, Romanian Journal of Economics, Institute of National Economy, vol. 33(2(42)), pp. $1-60$.

- Zaman, Gh., Goschin, Z., Vasile, V., 2013. Evoluția dezechilibrelor teritoriale din România în contextul crizei economice, Romanian Journal of Economics, vol. 37, issue 2(46), pp. 20-39. 